\title{
Total synthesis and cytotoxicity of the marine natural product malevamide $D$ and a photoreactive analog
}

\author{
Werner Telle ${ }^{1}$, Gerhard Kelter ${ }^{2}$, Heinz-Herbert Fiebig ${ }^{2}$, Peter G. Jones ${ }^{3}$
} and Thomas Lindel ${ }^{*}$

\author{
Full Research Paper \\ Address: \\ ${ }^{1}$ Institute of Organic Chemistry, TU Braunschweig, Hagenring 30, \\ 38106 Braunschweig, Germany, ${ }^{2}$ Oncotest Institute for Experimental \\ Oncology $\mathrm{GmbH}$, Am Flughafen 12-14, 79108 Freiburg, Germany \\ and ${ }^{3}$ Institute of Inorganic and Analytical Chemistry, TU \\ Braunschweig, Hagenring 30, 38106 Braunschweig, Germany \\ Email: \\ Thomas Lindel ${ }^{\star}$ - th.lindel@tu-braunschweig.de \\ * Corresponding author \\ Keywords: \\ cytotoxicity; diazirines; dolastatin analogs; marine natural products; \\ peptides; total synthesis
}

Beilstein J. Org. Chem. 2014, 10, 316-322. doi:10.3762/bjoc. 10.29

Received: 17 October 2013

Accepted: 03 January 2014

Published: 03 February 2014

This article is part of the Thematic Series "Natural products in synthesis and biosynthesis".

Guest Editor: J. S. Dickschat

(C) 2014 Telle et al; licensee Beilstein-Institut. License and terms: see end of document.

\begin{abstract}
The marine natural product malevamide D from the cyanobacterium Symploca hydnoides was synthesized for the first time. The final peptide coupling linked the dolaisoleuine and dolaproine subunits. The phenyl group of malevamide D was also functionalized with a photoreactive diazirine moiety, which was carried through seven reaction steps. Comprehensive assessment of the cytotoxicity in a panel of 42 human cancer cell lines revealed a geomean $\mathrm{IC}_{70}$ value of $1.5 \mathrm{nM}\left(\mathrm{IC}_{50} 0.7 \mathrm{nM}\right)$ for malevamide $\mathrm{D}$, whereas the photoreactive derivative proved to be less active by a factor of at least 200. COMPARE analysis indicated tubulin interaction as likely mode of action of malevamide D.
\end{abstract}

\section{Introduction}

The depsipeptide malevamide D (1, Figure 1) belongs to the dolastatin class of marine natural products and has been isolated from the cyanobacterium Symploca hydnoides by Scheuer and co-workers in 2002 ( $7.5 \mathrm{mg}, 0.014 \%$ of the dry weight) [1]. Malevamide D (1) was reported to exhibit in vitro cytotoxicity in the subnanomolar range ( $\mathrm{IC}_{50}$ values about $0.7 \mathrm{nM}$ ). Closely related to malevamide $\mathrm{D}(\mathbf{1})$ is isodolastatin $\mathrm{H}(\mathbf{2})$, which is also active in vivo, but slightly weaker than dolastatin 10 (3) [2].
Although there has been no study regarding the mode of action, it can be assumed that malevamide D (1) acts similarly to dolastatin 10 (3) by inhibiting the formation of microtubuli from tubulin and, thereby, cell division. Dolastatin-type natural products continue to be tested in clinical trials for cancer therapy [3]. This includes an antibody conjugate of monomethylauristatin $\mathrm{E}$ (MMAE), which has been approved for the treatment of Hodgkin lymphoma (Brentuximab vedotin) [4]. 
<smiles>CC[C@H](C)[C@H](C(=O)N[C@H](C(=O)N(C)C(C(C)C)[C@H](CC(=O)N1CCC[C@H]1[C@H](OC)[C@@H](C)C(=O)O[C@H](CO)Cc1ccccc1)OC)C(C)C)N(C)C</smiles>

1: malevamide D<smiles>CCC(C)[C@H](NC(=O)C(C(C)C)N(C)C)C(=O)N(C)[C@@H]([C@@H](C)CC)[C@H](CC(=O)N1CCCC1[C@H](OC)[C@@H](C)C(=O)O[C@H](CO)Cc1ccccc1)OC</smiles>

2: isodolastatin $\mathrm{H}$<smiles>CCC(C)[C@H]([C@H](CC(=O)N1CCC[C@H]1[C@H](OC)[C@@H](C)C(=O)N[C@H](Cc1ccccc1)c1nccs1)OC)N(C)C(=O)[C@@H](NC(=O)[C@@H](C(C)C)N(C)C)C(C)C</smiles>

3: dolastatin 10

Figure 1: Structures of the strongly cytotoxic marine natural products malevamide $\mathrm{D}(\mathbf{1})$, isodolastatin $\mathrm{H}(\mathbf{2})$, and dolastatin 10 (3).

In this paper, we report the first total synthesis of malevamide D (1) and an assessment of its in vitro cytotoxicity in a panel of 42 cell lines. We also synthesized a diazirinylated analog of $\mathbf{1}$, which, by photocrosslinking, might contribute to the understanding of the binding of $\mathbf{1}$ to tubulin.

\section{Results and Discussion \\ Total synthesis of malevamide $D$}

The natural products malevamide D (1), isodolastatin $\mathrm{H}(\mathbf{2})$, and dolastatin 10 (3) share two $\beta$-methoxy- $\gamma$-amino acid building blocks. The closest structural analog of malevamide D (1) is isodolastatin $\mathrm{H}$ (2) with an identical ester section composed of dolaproine and (2S)-3-phenylpropan-1,2-diol. On the N-terminal side, the isopropyl and two sec-butyl side chains of isodolastatin $\mathrm{H}(2)$ are replaced by one sec-butyl and two isopropyl side chains, respectively, in the case of malevamide D (1).

The total synthesis of $\mathbf{1}$ adopts the strategy by Yamada and co-workers in their total synthesis of $\mathbf{2}$, which sets the first retro cut at the tertiary amide bond between dolaisoleuine and dolaproine [2]. The tert-butyl ester 7 of Cbz-protected 3-methoxy-5-methyl-4-(methylamino)hexanoic acid (MMMAH) was obtained in multigram quantities within five steps from Cbz-valine (8), adapting a convenient sequence developed for dolaisoleuine by Pettit and co-workers [5]. Cbzprotected $N$-methylvalinol (4) [6] was oxidized to the aldehyde 5 under Parikh-Doering conditions, followed by aldol addition of the lithium enolate of $t$-BuOAc (Scheme 1). $\beta$-Hydroxyhexanoate 6 was obtained as a mixture of diastereomers (5:4), which was separated by column chromatography (silica) on a multigram scale. Treatment of $(3 R, 4 S)-6$ with Meerwein's salt in presence of proton sponge afforded Cbz-protected MMMAH tert-butyl ester 7 in $87 \%$ yield. There are also other, enantioselective syntheses of 7 [7] and Boc-protected versions of MMMAH [8,9], but we intended to also have the $(3 S)$-epimer of 7 at our disposal.

After hydrogenation of 7, the resulting secondary amine was coupled with Cbz-valine (8) affording dipeptide 9 (DEPCl, diethyl phosphorochloridate), $80 \%$ over two steps, Scheme 1). $N, N$-Dimethylisoleucine (10), obtained by reductive dimethylation of isoleucine with aqueous formaldehyde and $\mathrm{H}_{2}$ on $\mathrm{Pd} / \mathrm{C}$ $[10,11]$, was appended at the N-terminus (DEPC, diethyl phosphorocyanidate) affording tripeptide tert-butyl ester 11. Treatment with TFA liberated the free acid 12, which was coupled with the trifluoroacetate of dolaproine ester 13, liberated from the $N$-Boc-protected analog [2].

With the subsequent coupling step affording TBDPS-protected malevamide D (14), we initially had difficulties. It proved to be crucial to remove excess of TFA from both coupling partners 12 and 13 completely, by repeated evaporation of DCM solutions. Finally, a coupling yield of $68 \%$ was reached following the DEPC protocol. Desilylation (TBAF in $\mathrm{THF} / \mathrm{H}_{2} \mathrm{O}$ ) afforded 1 (HRESIMS found 755.49257, calcd. for $\mathrm{C}_{40} \mathrm{H}_{68} \mathrm{NaN}_{4} \mathrm{O}_{8}$ 755.49294 ) in $12 \%$ yield after 10 steps from valinol 4 (longest linear sequence). The optical rotation of the synthesized material $\left([\alpha]_{\mathrm{D}}{ }^{28}-37, c 0.09, \mathrm{MeOH}\right)$ is a little smaller than reported for the isolated natural product $\left([\alpha]_{\mathrm{D}}{ }^{26}-55, c 0.10\right.$, $\mathrm{MeOH})$ [1]. The ${ }^{1} \mathrm{H}$ and ${ }^{13} \mathrm{C}$ NMR spectra of 1 shows two sets of signals in a ratio of ca. 1:1. Clearly separated in the ${ }^{13} \mathrm{C}$ NMR spectrum are, for instance, the ester carbonyl signals of the conformers (174.0 and $173.3 \mathrm{ppm}$ ), the carbonyl signals of the pyrrolidine amide (170.5 and $170.6 \mathrm{ppm}$ ), and all phenyl carbon signals. Of the eastern section, only three of the four pyrrolidine carbon signals are broad. Most of the carbon signals of the western tripeptide of malevamide D are broadened (see Supporting Information File 1). The ${ }^{1} \mathrm{H}$ NMR spectrum shows many broad and overlapping signals, the assignment of which was only possible by careful interpretation of the 2D NMR data set. The only isolated signals belonging to different signal sets are located at $\delta_{\mathrm{H}} 3.84$ (one of the diastereotopic $\mathrm{OCH}_{2}$ signals) and $5.21 \mathrm{ppm}$ (acylated carbinol). The two sets of signals are probably caused by the presence of both conformers of the acyl pyrrolidine. An assignment of the data sets to either of the two conformers was not possible. The occurrence of conformers has been mentioned by Scheuer and co-workers and is also known for dolastatin 10 [12] and symplostatin 1 [13]. 
<smiles>C[14CH]/C(C)=C\C(=O)N(C)[C@H](CO)C(C)C</smiles>

4<smiles>CC(C)[C@H](C=O)N(C)C(=O)OC(C)(C)C</smiles>

5<smiles>CC(C)C(C(O)CC(=O)OC(C)(C)C)N(C)C(=O)OCc1ccccc1</smiles>

$(3 R, 4 S)-6$<smiles>COC(CC(=O)OC(C)(C)C)C(C(C)C)N(C)C(=O)OCc1ccccc1</smiles>
7<smiles>CC(C)[C@H](NC(=O)OCc1ccccc1)C(=O)O</smiles><smiles>COC(CC(=O)OC(C)(C)C)C(C(C)C)N(C)C(=O)[C@@H](NC(=O)OCc1ccccc1)C(C)C</smiles>

9

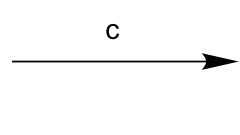

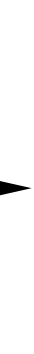<smiles>CCC(C)C(C(=O)O)N(C)C</smiles>

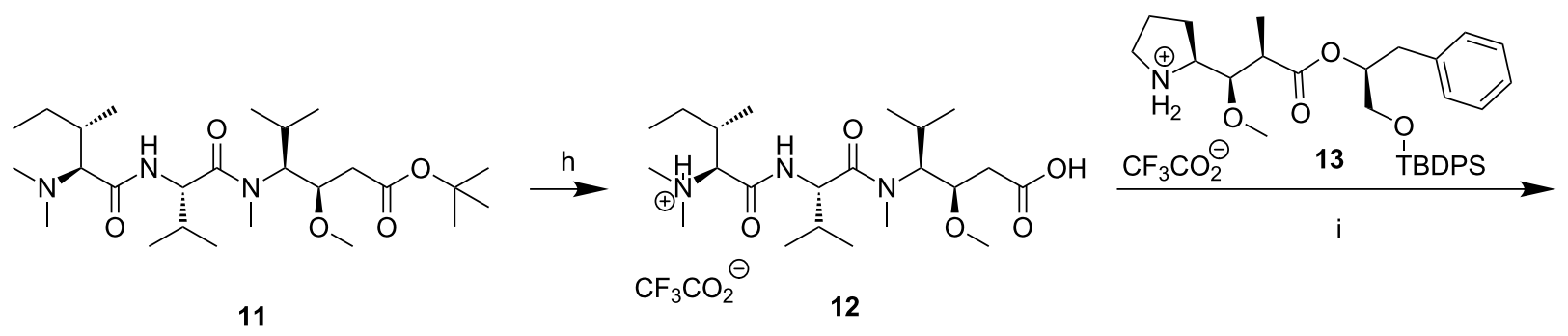

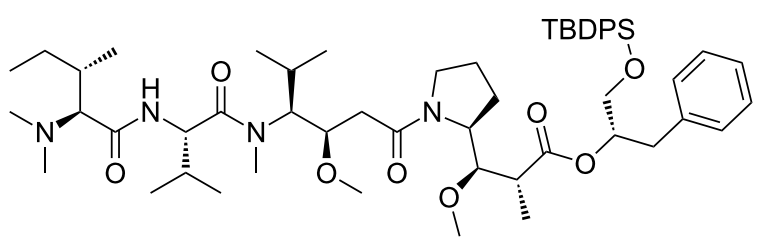

Scheme 1: Total synthesis of malevamide D (1). a) DMSO (16 equiv), $\mathrm{NEt}_{3}$ ( 5 equiv), pyridine $\cdot \mathrm{SO}_{3}\left(5\right.$ equiv), $0{ }^{\circ} \mathrm{C}, 1 \mathrm{~h}, 91 \%$. b) $\mathrm{LDA}(2.5 \mathrm{equiv})$, $t$-BuOAc (1.3 equiv), THF, $-78^{\circ} \mathrm{C}, 1 \mathrm{~h}$; separation of diastereomers, $(3 R, 4 S)-6: 47 \%$. c) 1,8-bis(dimethylamino)naphthalene (2.5 equiv), Me ${ }_{3} \mathrm{OBF}{ }_{4}$ (2.6 equiv), $4 \AA \mathrm{MS}, 1,2-\mathrm{DCE}, 0{ }^{\circ} \mathrm{C}, 2 \mathrm{~h}, \mathrm{rt}, 16 \mathrm{~h}, 87 \%$. d) $\left.\mathrm{H}_{2}, \mathrm{Pd} / \mathrm{C}(5 \%), \mathrm{MeOH}, \mathrm{rt}, 1 \mathrm{~h} . \mathrm{e}\right) 8$ (3 equiv), $\mathrm{NEt}_{3}$ (4 equiv), DEPCl (2 equiv), DCM, $0{ }^{\circ} \mathrm{C}$, $2 \mathrm{~h}, \mathrm{rt}, 16 \mathrm{~h}, 80 \%$ from 7. f) $\mathrm{H}_{2}, \mathrm{Pd} / \mathrm{C}(5 \%), \mathrm{MeOH}, \mathrm{rt}, 90$ min. g) 10 (3 equiv), NEt 3 (4 equiv), DEPC (1.5 equiv), DCM, $0{ }^{\circ} \mathrm{C}, 2 \mathrm{~h}, \mathrm{rt}, 16 \mathrm{~h}, 83 \%$ from 9. h) TFA, DCM, $0{ }^{\circ} \mathrm{C}, 90 \mathrm{~min}$, quant. i) 13 (1 equiv), $\mathrm{NEt}_{3}$ (6 equiv), DEPC (1.3 equiv), DCM, $0{ }^{\circ} \mathrm{C}$ to rt, $16 \mathrm{~h}, 68 \%$. j) TBAF-3H $\mathrm{H}_{2} \mathrm{O}(5 \mathrm{equiv}), \mathrm{THF} / \mathrm{H}_{2} \mathrm{O}$ 19:1, rt, 3 h, 71\%. DEPCl: diethyl phosphorochloridate; DEPC: diethyl phosphorocyanidate.

As an alternative route to the $\mathrm{N}$-terminal tripeptide 11, we also investigated the coupling of the $\mathrm{N}$-terminal dipeptide 15 with MMMAH tert-butyl ester (16, Scheme 2). However, after treatment of dipeptide 15 with secondary amine 16 ( 0.43 equiv) and DEPC (17, 2.5 equiv), the only isolable product was oxazolylphosphate 18 (35\%) without any amide formation occurring. The structure elucidation of $\mathbf{1 8}$ required $\mathrm{C}-\mathrm{P}$ coupling constant analysis, which showed doublet ${ }^{13} \mathrm{C}$ NMR signals of oxazole C-5 $(10 \mathrm{~Hz})$ and C-4 $(6.2 \mathrm{~Hz})$. To the best of our knowledge, this is only the second time that a peptidederived oxazol-5-ylphosphate has been characterized. Earlier, Boyd and co-workers had converted an oxazolone to an oxazolyl phosphate by treatment with excess diphenyl chlorophosphate [14]. In our case, a similar pathway is to be assumed with the oxazolone being formed first. The secondary amine $\mathbf{1 6}$ appears to react too slowly to be able to compete with oxazolone formation.

\section{Diazirinyl-substituted malevamide D}

Encouraged by the strong cytotoxicity of 1, we addressed the synthesis of a photoactivatable analog. The question was whether such a derivative would still be cytotoxic. The phenyl ring of 1 was chosen as location of a trifluoromethyldiazirinyl substituent. Pettit and co-workers have shown that introduction of a phosphate moiety at the $p$-position of the phenyl ring of auristatin PE did not lead to loss of cytotoxicity [3]. Recently, we have synthesized a hemiasterlin derivative with a diazirinylated indole moiety by incorporation of a thermally stable L-phototryptophan carrying a 1-azi-2,2,2-trifluoroethyl unit [15]. 
<smiles>CC[C@H](C)[C@H](C(=O)N[C@H](C(=O)O)C(C)C)N(C)C</smiles>

15

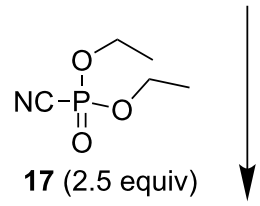

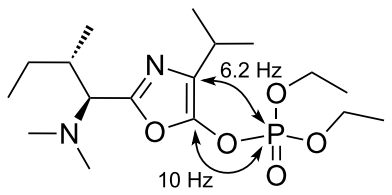

$18(35 \%)$
Scheme 2: Formation of oxazolylphosphate 18 on attempted DEPCmediated coupling of dipeptide 15 .

Racemic photo phenylpropanediol 25 was obtained starting from aryl(trifluoromethyl)ketone 19 (Scheme 3), which itself was synthesized via Grignard monoallylation of 1,4-dibromobenzene, followed by dihydroxylation, dioxolane protection and trifluoroacetylation of the remaining brominated position [16]. Refluxing of ketone 19 with $\mathrm{NH}_{2} \mathrm{OH} \cdot \mathrm{HCl}$ in pyridine led to nearly quantitative hydrolysis of the dioxolane affording diol oxime 20 as 95:5 mixture of $E$ - and $Z$-isomers. However, if solid $\mathrm{NaOH}$ was added to the reaction mixture and heated for several hours, the dioxolane survived, affording a 1:1 mixture of $E / Z$-oximes, which were tosylated after short work-up to $(E)$ and (Z)-22.

Reprotection of the diol unit of $\mathbf{2 0}$ and tosylation of $\mathbf{2 1}$ afforded tosyloxime $(E)-\mathbf{2 2}$, which crystallized overnight from the neat mixture and was analyzed by X-ray crystallography [17]. Thus, it became possible to assign the ${ }^{19} \mathrm{~F}$ NMR chemical shifts of both isomers $\left((E)-22: \delta_{\mathrm{F}}-66.9 ;(Z)-22: \delta_{\mathrm{F}}-61.9\right)$.

Conversion of $(E)-\mathbf{2 2}$ to diaziridine $\mathbf{2 3}$ (colorless solid, $\delta_{\mathrm{F}}$ $-75.96,-75.93$ ) was performed quantitatively (liquid $\mathrm{NH}_{3}$ in $t$-BuOMe, Scheme 4). As expected, the NMR spectra of the colorless solid $\mathbf{2 3}$ showed two sets of signals. Oxidation of $\mathbf{2 3}$ with $\mathrm{I}_{2} / \mathrm{NEt}_{3}$ to diazirine $24\left(\delta_{\mathrm{F}}-65.7\right)$ and acidic deprotection afforded diazirine diol 25 . Figure 2 shows the DSC (differential scanning calorimetry) profile of 25 , which melts at $54{ }^{\circ} \mathrm{C}$ and starts to decompose above $80^{\circ} \mathrm{C}$, indicating sufficient thermal stability for biological studies. Monosilylation of the primary hydroxy group of $\mathbf{2 5}$ afforded building block 26. Coupling with Boc-protected dolaproine (27, DCC/DMAP/CSA) yielded ester 28 as a mixture of two diastereomers. After deprotection of the

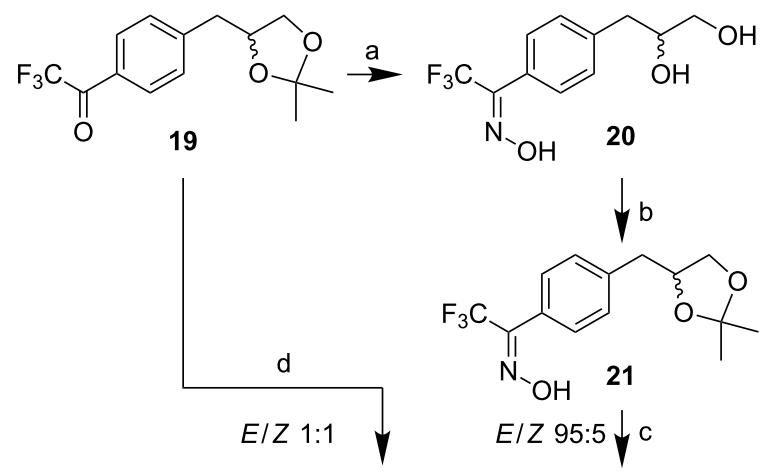<smiles></smiles>

(Z)-22

(E)-22

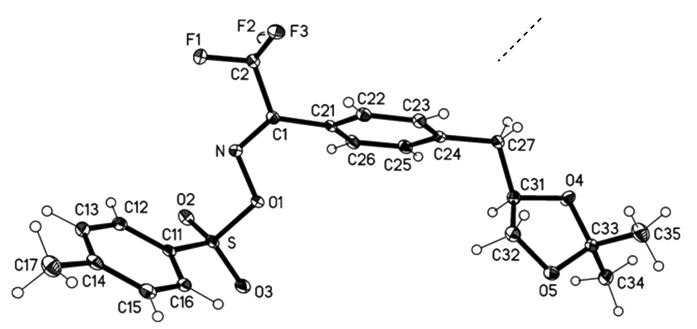

Scheme 3: Synthesis of tosyloximes (Z)-22 and (E)-22, X-ray structure of $(E)$-22. a) $\mathrm{NH}_{2} \mathrm{OH} \cdot \mathrm{HCl}$ (1.5 equiv), pyridine, reflux, $2 \mathrm{~h}, 80 \%$. b) 2,2-dimethoxypropane (12.4 equiv), $p$ - $\mathrm{TsOH} \cdot \mathrm{H}_{2} \mathrm{O}(5 \mathrm{~mol} \%)$, DMF, rt, $1 \mathrm{~h}, 95 \%$. c) $p-\mathrm{TsCl}$ (1.05 equiv), $\mathrm{NEt}_{3}$ ( 1.3 equiv), $\mathrm{DCM}, 0{ }^{\circ} \mathrm{C}$ to $\mathrm{rt}$, 18 h, $83 \%$. d) (i) $\mathrm{NH}_{2} \mathrm{OH} \cdot \mathrm{HCl}, \mathrm{NaOH}, \mathrm{EtOH}$, pyridine, reflux (for details see Supporting Information File 1); (ii) $p$ - $\mathrm{TsCl}$ (1.05 equiv), $\mathrm{NEt}_{3}$ (1.3 equiv), DCM, $0{ }^{\circ} \mathrm{C}$ to $\mathrm{rt}, 18 \mathrm{~h}, 74 \% .{ }^{19} \mathrm{~F}$ NMR chemical shifts (ppm) in $\mathrm{CDCl}_{3}$.

pyrrolidine, coupling with tripeptide 12 afforded $O$-silylated diazirinyl-substituted malevamide D (29,68\%). Desilylation (TBAF, THF $/ \mathrm{H}_{2} \mathrm{O}$ 19:1) led to a product mixture, the separation of which required semipreparative HPLC (RP-18, $\mathrm{MeOH} / \mathrm{H}_{2} \mathrm{O}$ 9:1). Diazirinyl-substituted malevamide 30 was obtained in 33\% isolated yield as a mixture of two epimers differing at the carbinol center (HRESIMS found 863.48644, calcd. for $\mathrm{C}_{42} \mathrm{H}_{67} \mathrm{NaF}_{3} \mathrm{~N}_{6} \mathrm{O}_{8}, 863.48647$ ). In the NMR spectra, four sets of signals were observed because of additional cis/ trans isomerism of the acyl pyrrolidine moiety. As in the case of $\mathbf{1}$, the tripeptidic western half showed mostly broad signals, whereas the signals of the phenyl carbons are resolved better, even if not fully separated.

\section{Cytotoxicity studies of malevamide $D$ and diazirinyl-substituted malevamide $D$}

The synthesized 1 proved to be potently cytotoxic with a geomean $\mathrm{IC}_{70}$ value of $1.5 \mathrm{nM}\left(\mathrm{IC}_{50} 0.7 \mathrm{nM}\right)$ in a panel of 
<smiles>FC(F)(F)C(F)(F)F</smiles>

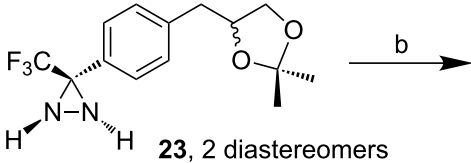<smiles>[Z4]C[C@]1(C)OC[C@@H](Cc2ccc(C3(C(F)(F)F)N=N3)cc2)O1</smiles>

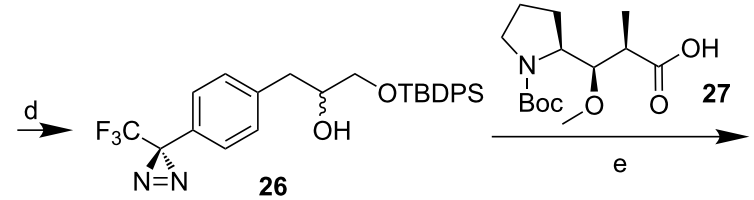<smiles></smiles><smiles>CCC(C)C</smiles><smiles>[R]OC[C@H](Cc1ccc(C2(C(F)(F)F)N=N2)cc1)OC(=O)C(C)[C@@H](OC)[C@H]1CCCN1C(=O)C[C@H](OC)[C@@H](C(C)C)N(C)C(=O)[C@@H](NC(=O)[C@@H]([C@@H](C)CC)N(C)C)C(C)C</smiles>

29: $\mathrm{R}=$ TBDPS $\stackrel{\mathrm{h}}{\longrightarrow}$ 30: $\mathrm{R}=\mathrm{H}$

Scheme 4: Synthesis of photo malevamide $\mathrm{D} 30$. a) $\mathrm{NH}_{3}(\mathrm{l}), t$-BuOMe, $-40^{\circ} \mathrm{C}, 2 \mathrm{~h}, \mathrm{rt}, 16 \mathrm{~h}$, quant. b) $\mathrm{I}_{2}$ (1.2 equiv), $\mathrm{NEt}_{3}$ (2.2 equiv), $\mathrm{Et}_{2} \mathrm{O}$, $0{ }^{\circ} \mathrm{C}, 15 \mathrm{~min}, \mathrm{rt}, 1 \mathrm{~h}, 99 \%$. c) THF, $2 \mathrm{~N} \mathrm{HCl}, \mathrm{rt}, 3 \mathrm{~h}, 97 \%$. d) TBDPSCl (1.1 equiv), imidazole (2.2 equiv), DMF, $0{ }^{\circ} \mathrm{C}, 1 \mathrm{~h}, 80 \%$. e) 27 ( 0.97 equiv), DMAP ( 0.41 equiv), DCC ( 1 equiv), CSA ( 0.23 equiv), $0{ }^{\circ} \mathrm{C}$ to rt, $16 \mathrm{~h}, 69 \%$. f) TFA, DCM, $0{ }^{\circ} \mathrm{C}, 90$ min. g) 12 (1 equiv), $\mathrm{NEt}_{3}$ (6 equiv), DEPC (2.14 equiv), DCM, $0{ }^{\circ} \mathrm{C}, 150 \mathrm{~min}, 68 \%$. h) TBAF $3 \mathrm{H}_{2} \mathrm{O}$ (5 equiv), THF/ $\mathrm{H}_{2} \mathrm{O} 19: 1,0{ }^{\circ} \mathrm{C}, 2 \mathrm{~h}, 33 \%$.
42 human cancer cell lines (see Table 1 and Supporting Information File 1). The cytotoxicity was about 10-fold higher than that of paclitaxel. The breast cancer cell lines MAXF-401 ( $\mathrm{IC}_{70}$ $0.2 \mathrm{nM})$ and MCF-7 (0.5 nM), the colon cancer cell lines HT-29 $(0.3 \mathrm{nM})$ and RKO $(0.5 \mathrm{nM})$, the lung cancer cell line $\mathrm{H} 460$ $(0.7 \mathrm{nM})$, the liver cancer cell line LIXF-575 (0.6 nM), and the renal cancer cell line RXF-393 $(0.4 \mathrm{nM})$ all proved to be very sensitive. Against 36 of the 42 cell lines, $\mathrm{IC}_{70}$ values of below $10 \mathrm{nM}$ were determined. The most resistant cell lines were shown to be RXF-1781 (kidney), CXF-269 (colon), MEXF-276

Table 1: Cytotoxicities $\left(\mathrm{IC}_{70}, \mathrm{IC} \mathrm{C}_{50}, \mathrm{nM}\right)$ of malevamide $\mathrm{D}(\mathbf{1})$ against selected human cancer cell lines. ${ }^{a}$

\begin{tabular}{llll} 
histotype & cell line & $\mathrm{IC}_{70}$ & $\mathrm{IC}_{50}$ \\
\hline Colon & HT-29 & 0.3 & 0.2 \\
Stomach & GXF-251 & 5.0 & 0.6 \\
Lung, adeno & LXFA-629 & 0.7 & 0.4 \\
Lung, large cell & LXFL-529 & 0.4 & 0.3 \\
Breast & MAXF-401 & 0.2 & 0.2 \\
Melanoma & MEXF-462 & 0.6 & 0.4 \\
Ovary & OVXF-899 & 1.0 & 0.7 \\
Pancreas & PAXF-1657 & 4.0 & 1.0 \\
Prostate & PRXF-22Rv1 & 0.8 & 0.6 \\
Mesothelioma & PXF-1752 & 0.4 & 0.3 \\
Kidney & RXF-486L & 0.7 & 0.5 \\
Uterus & UXF-1138L & 0.5 & 0.4 \\
\hline
\end{tabular}

aFor complete results in the panel of 42 human cancer cell lines and a COMPARE analysis, see Supporting Information File 1.

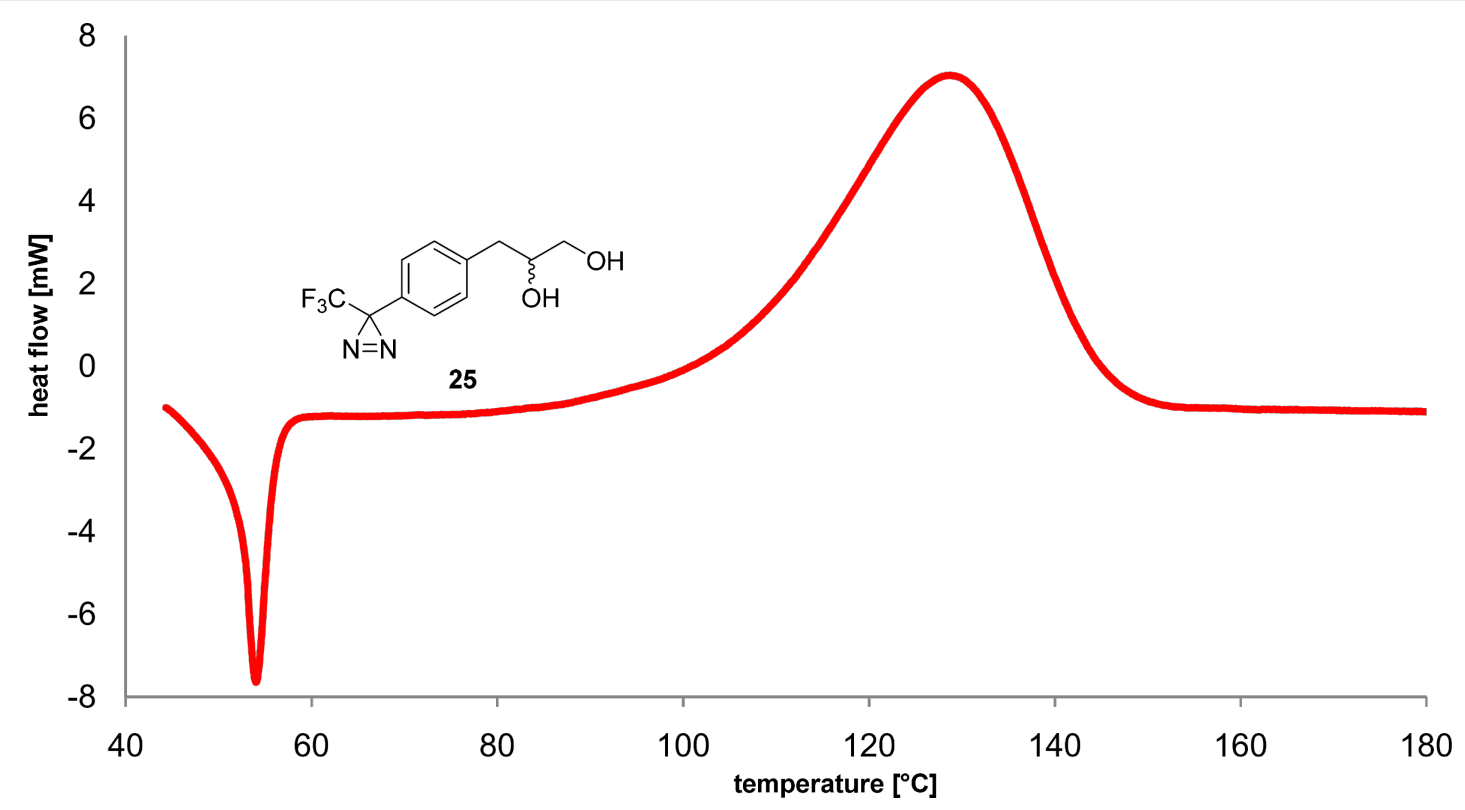

Figure 2: DSC curve of diazirine 25 , heating rate $5^{\circ} \mathrm{C} / \mathrm{min}$. 
(melanoma, $\mathrm{IC}_{70}$ about $50 \mathrm{nM}$, each), and in particular LXFA289 (lung, adenocarcinoma), PAXF-546L (pancreas), and PXF1118 (pleuramesothelioma, $\mathrm{IC}_{70}>100 \mathrm{nM}, \mathrm{IC}_{50}$ about $50 \mathrm{nM}$, each). Diazirinyl-substituted malevamide D 30 was about 200 times less cytotoxic than $\mathbf{1}$.

To obtain clues on the likely mode of action of $\mathbf{1}$ and $\mathbf{3 0}$, the in vitro activity data were compared with those of 177 reference compounds by COMPARE analysis. Individual $\mathrm{IC}_{50}$ values of a test compound were correlated with those of 177 reference compounds as determined for Oncotest's 42 cell line panel and expressed quantitatively as Spearman correlation coefficients (see Supporting Information File 1). Furthermore, 1 and $\mathbf{3 0}$ were correlated to each other. For compound 30, COMPARE analysis revealed the highest similarities towards tubulin interacting compounds like the vinca alkaloids vinfluine, vincristine, vindesine and the taxoid compound docetaxel. Furthermore, good correlations were detected towards PLK-1 inhibitors. Similar results were obtained for $\mathbf{1}$. Determining a Spearman coefficient of 0.742 between $\mathbf{1}$ and $\mathbf{3 0}$ suggested that these compounds share the same mode of action, most probably antimitotic activity based on tubulin interaction.

\section{Conclusion}

Our cytotoxicity test results for $\mathbf{1}$ confirm those obtained by Scheuer and co-workers who determined $\mathrm{IC}_{50}$ values of about $0.7 \mathrm{nM}$ against four cell lines (mouse lymphoma P-388, human lung carcinoma A-549, human colon carcinoma HT-29, human melanoma MEL-28) [1]. We had hoped that introduction of a Brunner-type diazirine unit in the para-position of the phenyl ring of $\mathbf{1}$ could lead to an analog that was still active, because it had been shown in several SAR studies that limited variation of the amine or alcohol component at the C-terminal amide or ester moieties of the dolastatin family members can be tolerated without much loss of cytotoxicity. This includes epimerization of the thiazole-carrying stereocenter of 3 [18], replacement of the phenyl by a methyl group, or removal of the thiazole ring [7]. Auristatins, of which some undergo clinical trials, are characterized by lacking the thiazole ring of $\mathbf{3}$ [19]. Pettit and co-workers prepared auristatin TP, which carries a phosphate unit in the para-position of the phenyl ring, and also two aminoquinoline derivatives that were as cytotoxic as dolastatin 10 [3]. Antibody conjugates of monomethylauristatin E functionalized on the C-terminal side have also shown promising pharmacological profiles [20,21]. However, compound $\mathbf{3 0}$ is at least 200 times less active than the natural product $\mathbf{1}$. Lower cytotoxicity may be associated with solubility problems. We will now search for more water-soluble, photoactivatable analogs of $\mathbf{1}$. Nunes and coworkers had synthesized a benzophenone-labelled derivative of the analog HTI-286, which competes with $\mathbf{3}$, and were able to identify $\alpha$-tubulin as binding partner [22].

\section{Supporting Information}

\section{Supporting Information File 1}

Procedures of synthesis and biotest, X-ray data and ${ }^{1} \mathrm{H}$,

${ }^{13} \mathrm{C}$ NMR spectra of selected compounds.

[http://www.beilstein-journals.org/bjoc/content/

supplementary/1860-5397-10-29-S1.pdf]

\section{Acknowledgements}

We thank Merck KGaA (Darmstadt, Germany) for the generous gift of chromatography materials. The BASF Group (Ludwigshafen, Germany) and Honeywell Specialty Chemicals Seelze GmbH (Seelze, Germany) are thanked for the donation of solvents.

\section{References}

1. Horgen, F. D.; Kazmierski, E. B.; Westenburg, H. E.; Yoshida, W. Y.; Scheuer, P. J. J. Nat. Prod. 2002, 65, 487-491. doi:10.1021/np010560r

2. Sone, H.; Shibata, T.; Fujita, T.; Ojika, M.; Yamada, K. J. Am. Chem. Soc. 1996, 118, 1874-1880. doi:10.1021/ja9519086

3. Pettit, G. R.; Hogan, F.; Toms, S. J. Nat. Prod. 2011, 74, 962-968. doi:10.1021/np1007334

4. Bradley, A. M.; Devine, M.; DeRemer, D. Am. J. Health-Syst. Pharm. 2013, 70, 589-597. doi:10.2146/ajhp110608

5. Pettit, G. R.; Sing, S. B.; Srirangam, J. K.; Hogan-Pierson, F.; Williams, M. D. J. Org. Chem. 1994, 59, 1796-1800. doi:10.1021/jo00086a034

6. Reddy, G. V.; Rao, G. V.; Sreevani, V.; Iyngar, D. S. Tetrahedron Lett. 2000, 41, 949-951. doi:10.1016/S0040-4039(99)02105-X

7. Miyazaki, K.; Kobayashi, M.; Natsume, T.; Gondo, M.; Mikami, T.; Sakakibara, K.; Tsukagoshi, S. Chem. Pharm. Bull. 1995, 43, 1706-1718. doi:10.1248/cpb.43.1706

8. Maugras, I.; Poncet, J.; Jouin, P. Tetrahedron 1990, 46, 2807-2816. doi:10.1016/S0040-4020(01)88373-3

9. Cella, R.; Venturoso, R. C.; Stefani, H. A. Tetrahedron Lett. 2008, 49, 16-19. doi:10.1016/j.tetlet.2007.11.031

10. Bowman, R. E.; Stroud, H. H. J. Chem. Soc. 1950, 1342-1345. doi:10.1039/jr9500001342

11. Aurelio, L.; Box, J. S.; Brownlee, R. T. C.; Hughes, A. B.; Sleebs, M. M. J. Org. Chem. 2003, 68, 2652-2667. doi:10.1021/jo026722I

12. Benedetti, E.; Carlomagno, T.; Fraternali, F.; Hamada, Y.; Hayashi, K.; Paolillo, L.; Shioiri, T. Biopolymers 1995, 36, 525-538. doi:10.1002/bip.360360414

13. Harrigan, G. G.; Luesch, H.; Yoshida, W. Y.; Moore, R. E.; Nagle, D. G.; Paul, V. J.; Mooberry, S. L.; Corbett, T. H.; Valeriote, F. A. J. Nat. Prod. 1998, 61, 1075-1077. doi:10.1021/np980321c

14. Boyd, V. L.; Bozzini, M.; Guga, P. J.; DeFranco, R. J.; Yuan, P.-M.; Loudon, G. M.; Nguyen, D. J. Org. Chem. 1995, 60, 2581-2587. doi:10.1021/jo00113a042

15. Wartmann, T.; Lindel, T. Eur. J. Org. Chem. 2013, 1649-1652. doi:10.1002/ejoc.201201726

16. Bolli, M.; Lehmann, D.; Mathys, B.; Müller, C.; Nayler, O.; Velker, J.; Weller, T. Novel thiophene derivatives. WO Patent WO 2006/100635 A2, Sept 28, 2006. 
17. CCDC 956232 contains the supplementary crystallographic data of compound $(E)-22$, which can be obtained free of charge from the Cambridge Crystallographic Data Centre via http://www.ccdc.cam.ac.uk/data_request/cif (12, Union Road, Cambridge CB21EZ, UK; fax: (+44) 1223-336-033; or deposit@ccdc.cam.ac.uk).

18. Bai, R.; Roach, M. C.; Jayaram, S. K.; Barkoczy, J.; Pettit, G. R.; Ludueña, R. F.; Hamel, E. Biochem. Pharmacol. 1993, 45, 1503-1515. doi:10.1016/0006-2952(93)90051-W

19. Shnyder, S. D.; Cooper, P. A.; Millington, N. J.; Pettit, G. R.; Bibby, M. C. Int. J. Oncol. 2007, 31, 353-360

20. Doronina, S. O.; Bovee, T. D.; Meyer, D. W.; Miyamoto, J. B.; Anderson, M. E.; Morris-Tilden, C. A.; Senter, P. D. Bioconjugate Chem. 2008, 19, 1960-1963. doi:10.1021/bc800289a

21. Axup, J. Y.; Bajjuri, K. M.; Ritland, M.; Hutchins, B. M.; Kim, C. H.; Kazane, S. A.; Halder, R.; Forsyth, J. S.; Santidrian, A. F.; Stafin, K.; Lu, Y.; Tran, H.; Seller, A. J.; Biroc, S. L.; Szydlik, A.; Pinkstaff, J. K.; Tian, F.; Sinha, S. C.; Felding-Habermann, B.; Smider, V. V.; Schultz, P. G. Proc. Natl. Acad. Sci. U. S. A. 2012, 109, 16101-16106. doi:10.1073/pnas.1211023109

22. Nunes, M.; Kaplan, J.; Wooters, J.; Hari, M.; Minnick, A. A., Jr.; May, M. K.; Shi, C.; Musto, S.; Beyer, C.; Krishnamurthy, G.; Qiu, Y.; Loganzo, F.; Ayral-Kaloustian, S.; Zask, A.; Greenberger, L. M. Biochemistry 2005, 44, 6844-6857. doi:10.1021/bi0474766

\section{License and Terms}

This is an Open Access article under the terms of the Creative Commons Attribution License (http://creativecommons.org/licenses/by/2.0), which permits unrestricted use, distribution, and reproduction in any medium, provided the original work is properly cited.

The license is subject to the Beilstein Journal of Organic Chemistry terms and conditions:

(http://www.beilstein-journals.org/bjoc)

The definitive version of this article is the electronic one which can be found at: doi:10.3762/bjoc.10.29 